\title{
Revised models for the proportion of suspended sediments in hillslope soil loss - an empirical understanding
}

\author{
D. Mark Silburn ${ }^{1,2}$ \\ ${ }^{1}$ Department of Resources, Queensland, 2 Centre for Agricultural Engineering, University of Southern \\ Queensland, Queensland \\ Email: mark.silburn@resources.qld.gov.au
}

\begin{abstract}
This paper investigates the proportion of suspended sediment in hillslope erosion using measured data and presents preliminary models. The P2R Dynamic-SedNet (PD-SedNet) model calculates the proportion of suspended sediment in runoff from hillslope erosion as directly proportional to the proportion of dispersed silt and clay in the surface soil. However, many soils are composed of and erode as a large proportion of aggregates of primary particles. Exceptions occur where the surface soil is dispersive, non-cohesive (e.g., loose sand), or where the sediment is eroded from a hard-set surface. Laboratory data for bare, rainfall wet surface soils indicate that the proportion of fine particles $(<0.125 \mathrm{~mm})$ increases until surface soil silt and clay is $50 \%$ and then flatten at about $25 \%$ suspended sediment. Suspended sediment is lower than the PD-SedNet equation for soil silt and clay greater than $15 \%$. An equation (modified Loch/Lu) was fitted to these laboratory data. Suspended sediment data for eight plots and catchments in Queensland and six in SE Asia with bare soil were also plotted against soil silt and clay, and the PD-SedNet and modified Loch/Lu equations. Two relationships emerged: 1) data for dispersive, mulga, non-cohesive and hardsetting soils fit around the PD-SedNet line, and 2) data for "aggregated soils" fit around the modified Loch/Lu line. For aggregated soils, when soil silt and clay is 60\%, PD-SedNet proportion of suspended sediment is $60 \%$ while the data/Loch/Lu equation indicates it is $\sim 25 \%$. That is, the PD-SedNet equation gives a large overestimate for bare, aggregated soils.

However, much of Queensland's cropping and grazing land is not bare. Data from two studies in grazing and three in cropping show that the proportion of suspended sediment increases with increasing cover. The proportion of suspended sediment is strongly related to ground cover for grazing and cultivated catchments, but the relationship differed for different soils. As cover increases, the proportion of suspended sediment approaches the PD-SedNet line. However, at high enough cover the proportion of suspended sediment exceeds that calculated with the PD-SedNet equation. For example, for the Wallumbilla Grey Vertosol, the soil silt plus clay is $48 \%$, giving a PD-SedNet estimate of suspended sediment of $48 \%$ whereas the Wallumbilla suspended sediment can vary from 17 to $80 \%$ depending on cover. A more general method is needed to estimate the proportion of suspended sediment. This method needs to account for the effects of soil and cover as shown here, and other factor known to affect the proportion of suspended sediment, such as prior land use and slope. The results presented here are at small plot and catchment scale; an unresolved issue remains that coarser sediment will continue to be deposited with increasing scale. At what scale should suspended sediment be defined? Future work should concentrate on deriving more relationships with cover and finding a method for predicting these relationships based on commonly available data and resolving the scale issue.
\end{abstract}

Keywords: Cover, Great Barrier Reef(GBR), soil erosion, sediment delivery, sediment size 
Silburn, Revised models for the proportion of suspended sediments in hillslope soil loss - a empirical understanding

\section{INTRODUCTION}

Suspended sediment is a major contributor to poor marine water quality in the Great Barrier Reef (GBR) (McCloskey et al., 2021). Gullies are the major source of sediment, with comparable contributions from hillslopes and streambanks (McCloskey et al., 2021). Approximately half of generated sediment is delivered to the GBR lagoon; the remainder is deposited on floodplains, trapped in reservoirs etc. Grazing lands contribute 53\% of the fine sediment, while conservation lands contribute a further $13 \%$ (a function of their relatively large areas); the remainder is sourced from a range of other land uses. However, sediment from other land uses can be locally significant. Soils in the GBR catchment include a wide range; the dominant soil are Sodosols, Vertosols, Kandosols, Rudosols and Chromosols.

The Paddock to Reef Dynamic-SedNet model (Waters 2014) calculates the proportion of suspended sediment in hillslope erosion as directly proportional to the proportion of dispersed silt and clay in the surface soil:

TSS load to stream $(\mathrm{kg} /$ day $)=$ RUSLE sediment load $(\mathrm{kg} /$ day $) *($ silt + clay $) *$ HSDR $\quad$ Eqn 1

where RUSLE is the Revised Universal Soil Loss Equation (Renard et al., 1997), silt and clay are proportions and HSDR is a Hill Slope Deliver Ratio. This differs from the SedNet model of Wilkinson et al., (2014) by including the silt + clay term. The SedNet fine sediment budget is for silt and clay sized sediment $(<20 \mu \mathrm{m})$, rather than for 'suspended sediment'. Sediment delivery ratios of 0.03 to 0.3 are applied in PD-SedNet (McCloskey et al., 2021).

Soils are often composed of, and eroded as, aggregates of primary particles (Figure 1) which are water stable (Meyer et al. 1980; Meyer 1985). The PD-SedNet relationship does not attribute any variation in the proportion of suspended sediment to the degree of aggregation of soils. Aggregates are coarser than the dispersed soil particles, being composed of amalgamations of primary particles, but have lower density. Meyer (1985) found sediment from interrill plots (on 17 soils in US croplands) contained only 55\% of the silt and clay sized particles found in the dispersed soil, the remainder being bound into aggregates. Exceptions occur where the surface soil is dispersive, non-cohesive (e.g., loose sand), or where the sediment is eroded from a hard-set surface and has a sediment particle size distribution like or mostly like the dispersed surface soil (Silburn et al. 2011), i.e. the sediment contains a small proportion of aggregated particles. The relationship used in PD-SedNet would be corrected for these cases. In this paper, relationships are derived to estimate the proportion of suspended sediment in hillslope soil loss, using measured data.

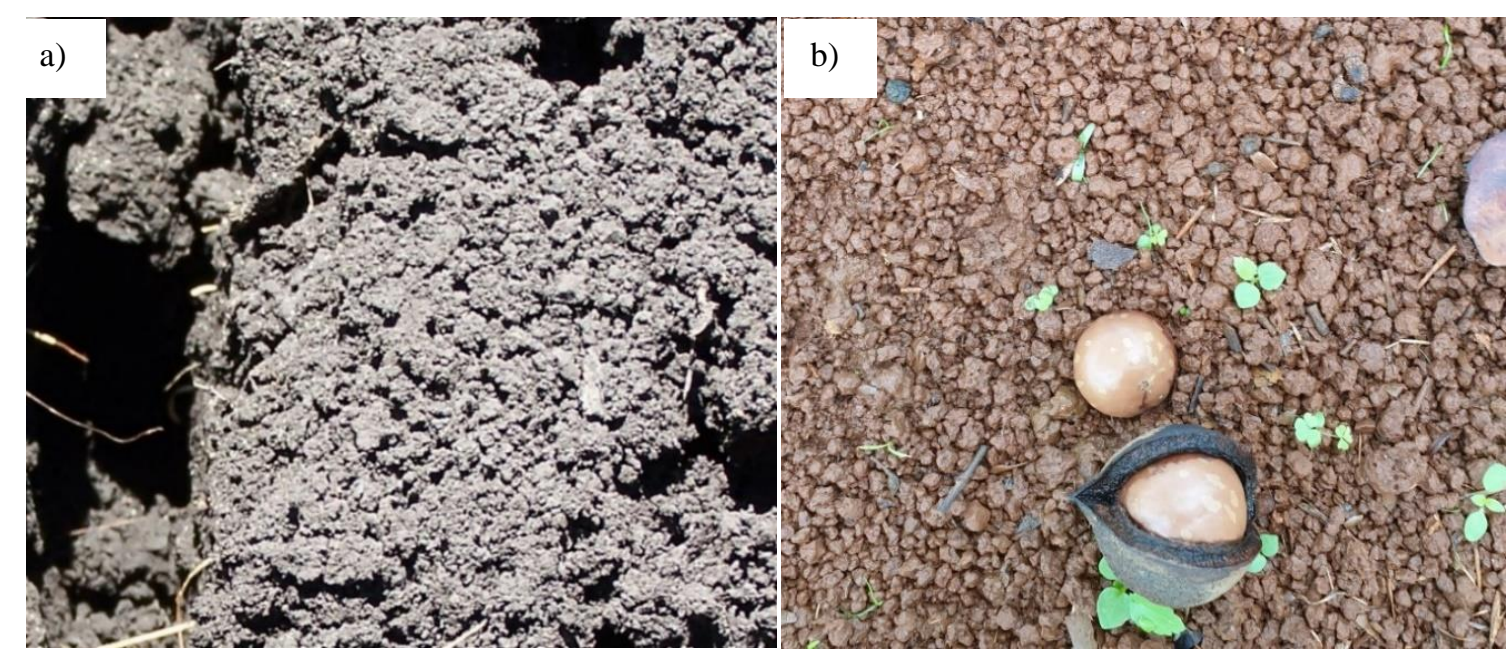

Figure 1. Surface of a) a Vertosol and b) a Ferrosol, with aggregated particles (\& macadamias). Upon wetting these aggregates break down to smaller aggregates with some primary particles.

\subsection{What sediment sizes occur in hillslope erosion and in streams?}

Data on sediment sizes in runoff for small catchments in Queensland are rare. Freebairn and Wockner (1986a) found from wet sieving suspended sediments (after settling of coarser particles) that all sediments were $<0.125$ $\mathrm{mm}$ (the finest sieve) on cultivated Vertosols. In contrast, sediment eroded in rills had only $\sim 12 \%<0.125 \mathrm{~mm}$ particles for the Black Vertosol and $\sim 40 \%$ for the Grey Vertosol (Freebairn and Wockner, 1986b). Thus, all particles $>0.125 \mathrm{~mm}$ eroded in the rills were deposited in the contour bank channel. In semi-arid grazing lands with hard set surface soils, Silburn et al. (2011) found 90-98\% of suspended sediment was fine-sized $(<0.053$ $\mathrm{mm})$. Clay-sized sediment $(7-14 \%)$ was depleted in suspended sediment, compared with $18-24 \%$ in soil, indicating that some clay was transported in aggregates of silt size or larger. That is, sediment from hard set soils 
Silburn, Revised models for the proportion of suspended sediments in hillslope soil loss - a empirical understanding

was mostly, but not fully disaggregated. Thornton and Elledge (2019) found for bare fallow and heavily grazed small catchments, $93 \%$ of sediment in runoff was $<0.016 \mathrm{~mm}$ size.

The predominance of $<0.016 \mathrm{~mm}$ sediments from small catchments is the same at larger catchment scales. Packett et al. (2009) in the Fitzroy River and Bainbridge et al. (2014) and Bainbridge et al. (2016) in the Burdekin and Wet tropics found that most of the sediment was $<0.020 \mathrm{~mm}$. However, smaller, wetter coastal catchments have coarser sediments with more (65-75\%) 0.016-0.63 mm sediment than larger, drier catchments. Overall, sediment in runoff from small catchments and streams was of fine sizes.

\section{RESULTS AND DISUSSION}

\subsection{Estimating the proportion of suspended sediment in runoff}

Two types of data were used to develop equations for estimating suspended sediment in runoff. Firstly, Loch et al. (1998) measured the sizes of particles in rainfall wet surface soils. The finest size measured was $<0.125 \mathrm{~mm}$ $\left(\mathrm{P}_{125}\right)$. This was used as a surrogate for suspended sediment. Lu et al. (2003) fitted an equation between these $\mathrm{P}_{125}$ data, as a proportion of $\mathrm{P}_{125^{*}}$ of the dispersed soil (sum of clay, silt and fine sand $(<0.125 \mathrm{~mm})$ ), and the dispersed clay in the surface soil (their Fig. $2 ; \mathrm{P}_{125} / \mathrm{P}_{125^{*}}=100 * \operatorname{Exp}(-0.019$ Clay\%)). This provided a model for the proportion of fine particles in a wide range of Queensland cropping soils. Secondly, these data were compared with data for suspended load from bare hillslope plots and catchments (Table 1).

\subsection{Suspended sediment data for bare conditions}

Data for suspended sediment as a proportion of total soil loss for bare plots were taken from eight small catchment or plots in Queensland and six plots in SE Asia (Table 1). The Queensland catchments had surface clay contents ranging from 9-62\%. Four of the plots were uncultivated bare scalds (3 at Springvale and 1 at Mt. Mort). The SE Asia (ACIAR) sites had surface clay contents of 2-56\%. Two of the sites had dispersive soil (Kenmaman and Springvale eroded), and one was sandy and non-cohesive (Goomborian). Two of the SE Asian sites had high organic matter $(\sim 5 \%)$ (Los Banos and ViSCA). Thus, while the number of sites is limited, they do have a wide range of soil texture. Plots were only 10 's of $\mathrm{m}^{2}$ in area while catchments were 0.7 to $\sim 6$ ha. The Asian data represent widely different soils to the Queensland one. This diversity is a good test of the robustness of the model.

Table 1. Small catchments and plots with data for suspended and total sediment loads, for bare soils.

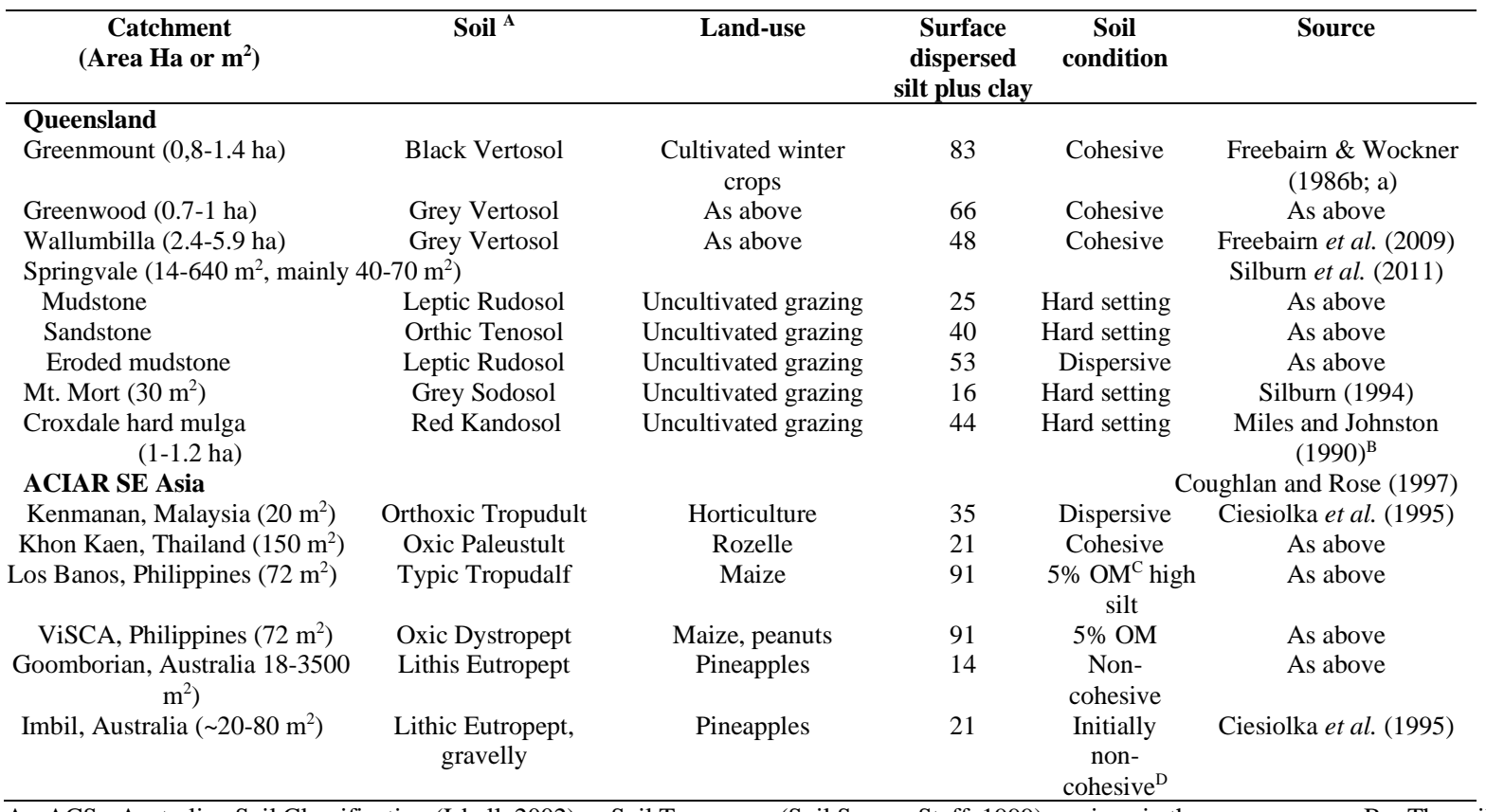

A - ACS - Australian Soil Classification (Isbell, 2002) or Soil Taxonomy (Soil Survey Staff, 1999) as given in the source papers. B - The soil data were reported in Silburn et al. (2011). C - OM organic matter content. D - The soil consolidated over time and a stone armoured surface was created as fines were removed by erosion (Ciesiolka et al. 1995).

The Loch data for $\mathrm{P}_{125}$ and the proportion of suspended sediment from the catchments are ploted against their soil silt and clay content in Figure 2. Given these $\mathrm{P}_{125}$ data in Figure 2 are plotted against $\%$ silt plus clay rather than $\%$ clay as used by Lu et al. (2003), a new equation was fitted giving $\mathrm{Y}=-0.0068 \mathrm{X}^{2}+0.8893 \mathrm{X}\left(\mathrm{R}^{2}=0.73\right)$, where $\mathrm{X}=\%$ dispersed silt plus clay and $\mathrm{Y}=\mathrm{P}_{125}$. This was used as a first approximation of the catchment data in Figure 2. Data for interrill erosion on 17 US cultivated soils (Meyer 1985) also fits this relationship except for two points that are underestimated by $12-15 \%$ suspended sediment (data not shown). 
Silburn, Revised models for the proportion of suspended sediments in hillslope soil loss - a empirical understanding

Two relationships emerged: 1) dispersive, mulga, non-cohesive and some hardsetting soils fit around the PDSedNet line (Figure 2), and 2) aggregated soils fit around the modified Loch/Lu line. The aggregated soils do not fit the PD-SedNet line. For the Lu/Loch line, the proportion of suspended sediment initially increases and then flattens out (or declines) as silt and clay increases. For higher silt and clay soils, there is a large and increasing discrepancy in the proportion of suspended sediment between the PD-SedNet and Loch/Lu lines. Data for Greenmount is below the fitted line, which may indicate less suspended sediment at high silt and clay contents, but this cannot be confirmed with the data available here. Two sites from SE Asia also had low suspended sediment. These soils had high organic matter content and one had high silt. Relationships are shown (Figure 2), for the two classes of soils. Thus, the proportion of suspended sediment can be estimated from commonly available soil properties, for bare soils.

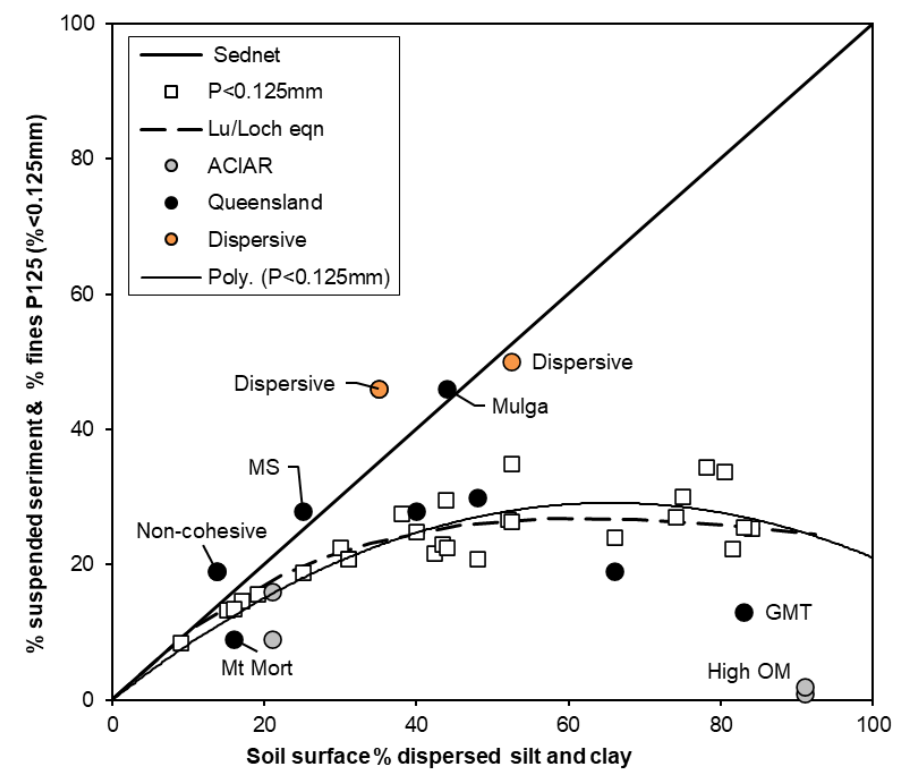

Figure 2. Proportion of suspended sediment for Queensland and SE Asian plots and catchments with bare soil. Greenmount (GMT). Springvale mudstone derived soil (MS), Mulga and Mt Mort have hardsetting surfaces.

\subsection{Effect of cover on the proportion of suspended sediment}

Young (1980) found for six of seven US cropping studies, the proportion of sediment particles $>0.05 \mathrm{~mm}$ decreased substantially with increasing cover, i.e., fines increased. However, the proportion of clay-sized sediment $(<0.002 \mathrm{~mm})$ increased with increasing cover. Scanlan et al. (1996) and Silburn et al. (2011) also showed the proportion of suspended load increases with increasing cover (pasture biomass and litter) in grazing lands. Silburn (2011a) fitted simple models for his suspended load and bed load against cover. When these were recombined to estimate the proportion of suspended load, curvilinear relationships resulted (Figure 3). Soil derived from mudstone and from sandstone had similar relationships while those on somewhat sodic eroded mudstone were different with greater suspended sediment.

Here further data are presented for three cultivated cropping catchment studies with a range of tillage and crop treatments. Cover entailed crop residue (stubble) and some time standing crop canopy cover. The proportion of suspended sediment increases with increasing cover for all three studies (Figure ) with generally good relationships for most wheat and wheat stubble (tillage) treatments. However, some treatments such as zero-till and wheat, and sunflowers, for the Acland Grey Vertosol have higher and lower suspended sediment than the other tillage treatments, respectively (Figure a). The suspended proportions for two Grey Vertosols (Acland and Wallumbilla) have similar relationships to cover, with slopes of 0.01 , whereas the Black Vertosol has a lower slope (Figure a). The Grey Vertosols have rainfall wet $\mathrm{P}<0.125 \mathrm{~mm}$ of $26 \%$ and $44 \%$, respectivily, while the Black Vertosol has only 18\% (Foley and Silburn 2002), that is, has less fine particles.

While a curvialiear relationship (Figure 3) is logical if both suspended and bed load have a declining exponential relationship with cover, the data for the three cropping sites appear to fit a linear relationship. This may be because the soil loss-cover relationship is less steep for the cropping sites than for grazing sites. While the relationship expected is now clearer, there are large differences between sites. Thus, a general model is not available for inclusion in a catchment model. A future step is to relate the slopes of the suspended load vs cover linear regressions soil and sediment properties. 
Silburn, Revised models for the proportion of suspended sediments in hillslope soil loss - a empirical understanding

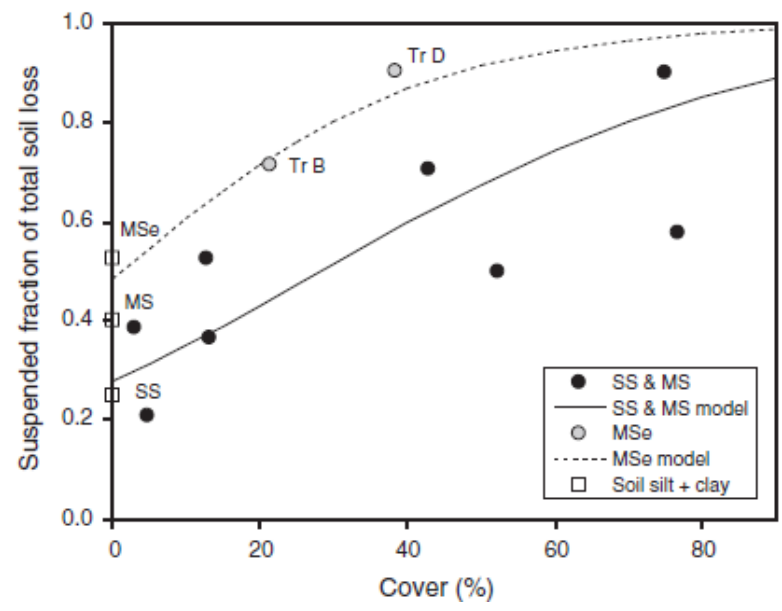

Figure 3. Effect of cover on the proportion of suspended sediment for sandstone (SS), mudstone (MS), and eroded mudstone (MSe) derived soils. (Source: Silburn et al. (2011)).

As cover increases the proportion of suspended sediment approaches the PD-SedNet line. However, at high enough cover, the proportion of suspended sediment exceeds that calculated with the PD-SedNet equation. For example, for the Wallumbilla Grey Vertosol the soil silt and clay is 48\%, giving a PD-SedNet estimate of suspended sediment of $48 \%$ whereas the Wallumbilla suspended sediment can vary from $17-80 \%$ depending on cover. A more general method is needed to estimate the proportion of suspended sediment. This method needs to account for the effects of soil and cover as seen in Figure 2 and Figure 3, repectively, and other factor mensioned below. Other factors will also affect sediment sizes in runoff, a major one being prior land use; soil aggregates are larger when soil has never been cultivated, under pasture or forest. The tillage trial catchment data also indicates that taller crop canopies such as sunflower and sorghum have lower suspended load proportions than shorter crops (Figure 4a). The proportion of suspended sediment also decreases with increasing slope up to $10 \%$ slope then was constant (Young, 1980) as runoff has more capacity to transport larger particles on steeper slopes.
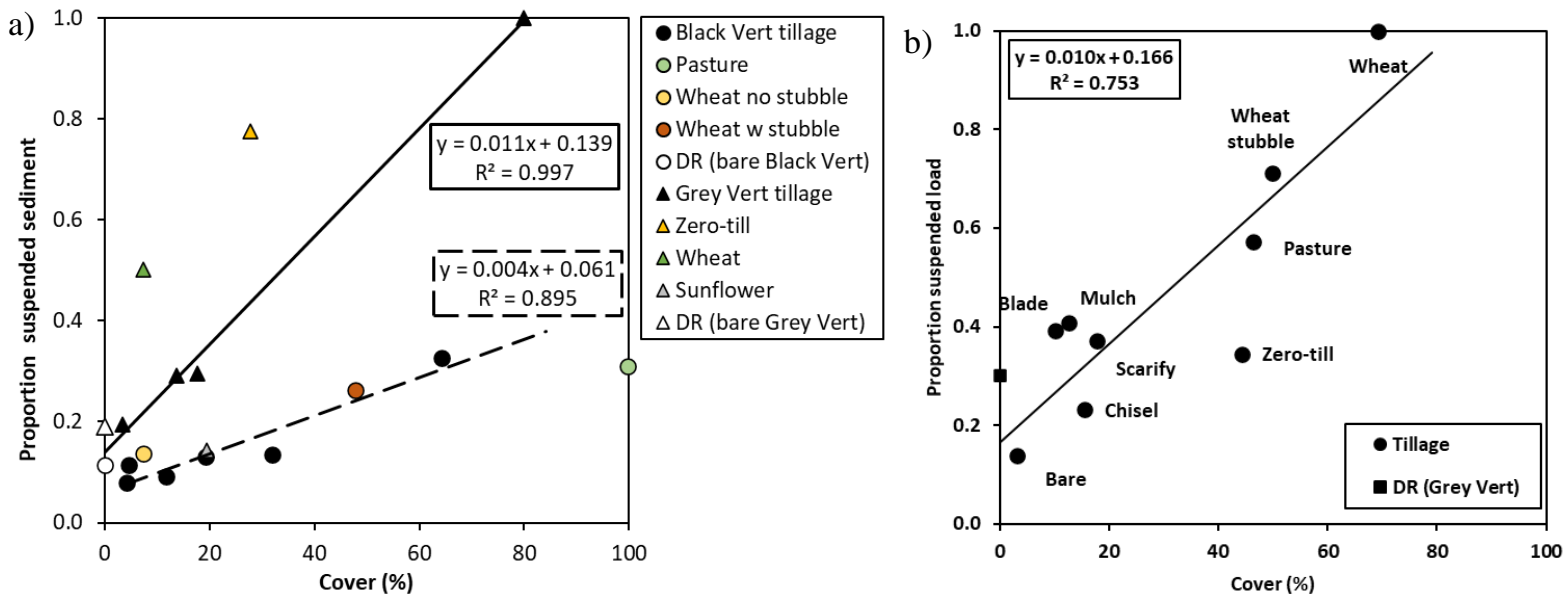

Figure 4. Effects of cover on the proportion of suspended sediment at a) Greenmount (Black Vertosol) and Acland (Grey Vertosol), summer fallow tillage treatments (stubble burnt, incorporated, mulched \& zero-tillage) \& other crops, and b) Wallumbilla (Grey Vertosol) tillage trial. Delivery ratios (DR) for bare soil are also shown.

\section{Cover C-Factor relationships}

There is considerable evidence that the default Revised Universal Soil Loss Equation (RUSLE) (Renard et al., 1997) cover C-factor relationship typically overpredicts soil loss in Queensland (Freebairn and Wockner 1986b; Loch 2000; Rosewell 1990; Silburn et al. 2011). The measured relationships are steeper than the RUSLE default. The RUSLE cover C-factor relationship was derived for cropping soil in the US, which are generally siltier than Queensland cropping soils; Queensland soils are generally higher in clay and lower in silt. Any future evaluation of sediment modelling in Queensland should investigate effects of changing this relationship.

\section{CONCLUSIONS AND RECOMMENDATIONS}

Data for plots and catchments were analysed to determine the relationship between the proportion of hillslope soil loss as suspended load on bare plots and compared to the equation used in PD-SedNet. Two relationships 
Silburn, Revised models for the proportion of suspended sediments in hillslope soil loss - a empirical understanding

emerged: 1) dispersive, mulga, non-cohesive and some hard-setting soils fit around the PD-SedNet line; and 2) aggregated soils fit around the modified Loch/Lu line. For aggregated soils, the PD-SedNet equation greatly overestimates the proportion of soil loss that is suspended sediment. The proportion of suspended sediment was then related to ground cover for data from grazing and cropping experiments. The proportion of suspended sediment increased with increasing cover and was well related to cover for grazing and cultivated catchments $\left(\mathrm{R}^{2}\right.$ 0.75-0.99), but the relationship differed for different soils. The results presented here are at small plot and catchment scale; an unresolved issue remains that coarser sediment will continue to be deposited with increasing scale. Future work should concentrate on deriving more relationships with cover and on finding a method for predicting these relationships based on commonly available data and resolving the scale issue.

\section{ACKNOWLEDGEMENTS}

This work is jointly funded by the Australian and Queensland Governments through the Paddock to Reef Program. Shawn Darr (Resources), Dr. Scott Wilkinson (CSIRO) and Dr. Daren Hamel (USDA) provided very useful corrections and comments on the manuscript.

\section{REFERENCES}

Bainbridge, Z.T., Lewis, S.E., Smithers, S.G., Kuhnert, P.M., Henderson, B.L., Brodie, J.E., Henderson, Brent L. Brodie, J.E., 2014. Fine-suspended sediment and water budgets for a large, seasonally dry tropical catchment: Burdekin River catchment, Queensland, Australia. Water Resour. Res. 50, 9067-9087. https://doi.org/10.1002/2013WR014979

Ciesiolka, C.A., Coughlan, K.J., Rose, C.W., Escalante, M.C., Hashim, G.M., Paningbatan, E.P., Sombatpanit, S., 1995. Methodology for a multi-country study of soil erosion management. Soil Technol. 8, $179-192$. https://doi.org/10.1016/0933-3630(95)00018-6

Ciesiolka, C.A.A., 1992. The constraints to conservation in steeplands: A case study of a pineapple farm at Imbil, South East Queensland., in: Proceedings of the Second International Symposium on Integrated Land Use Management for Tropical Agriculture. Queensland Department of Primary Industries. QC92009., Brisbane, Australia, pp. 1-7.

Coughlan, K.J., 1997. Description of sites, experimental treatments and methodology, in: Coughlan, K. J. and Rose, C.W. (Ed.), A New Soil Conservation Methodology and Application to Cropping Systems in Tropical Steelands. Australian Centre for International Agricultural Research (ACIAR), pp. 3-8.

Coughlan, K.J., Rose, C.W., 1997. Field experimental results - Runoff, soil loss and crop yield. ACIAR Technical Report 40., in: Coughlan, K., Rose, C. (Eds.), A New Soil Conservation Methodology and Application to Cropping Systems in Tropical Steeplands. Australian Centre for International Agricultural Research (ACIAR), Canberra, pp. 9-23.

Foley, J.L., Silburn, D.M., 2002. Hydraulic properties of rain impact surface seals on three clay soils - Influence of raindrop impact frequency and rainfall intensity during steady state. Aust. J. Soil Res. 40, 1069-1083. https://doi.org/10.1071/SR01112

Freebairn, D.M., Wockner, G.H., 1986a. A study of soil erosion on vertisols of the Eastern Darling Downs, Queensland. II The effect of soil, rainfall, and flow conditions on suspended sediment losses. Aust. J. Soil Res. 24, 159-172.

Freebairn, D.M., Wockner, G.H., 1986b. A study of soil erosion on vertisols of the Eastern Darling Downs, Queensland. I Effects of surface conditions on soil movement within contour bay catchments. Aust. J. Soil Res. 24, 135-158.

Freebairn, D.M., Wockner, G.H., Hamilton, N., Rowland, P., 2009. Impact of soil conditions on hydrology and water quality for a brown clay in the north-eastern cereal zone of Australia. Aust. J. Soil Res. 47, 389-402. https://doi.org/10.1071/SR07054

Isbell, R.F., 2002. The Australian soil classification, The Australian soil classification. CSIRO, Collingwood. https://doi.org/10.1016/s0016-7061(96)00096-1

Loch, R.J., 2000. Effects of vegetation cover on runoff and erosion under simulated rain and overland flow on a rehabilitated site on the Meandu Mine, Tarong, Queensland. Aust. J. Soil Res. 38, $299-312$. https://doi.org/10.1071/SR99030

Lu, H., Prosser, I.P., Moran, C.J., Gallant, J.C., Priestley, G., Stevenson, J.G., 2003. Predicting sheetwash and rill 
Silburn, Revised models for the proportion of suspended sediments in hillslope soil loss - a empirical understanding

erosion over the Australian continent. Aust. J. Soil Res. 41, 1037-1062. https://doi.org/10.1071/SR02157

McCloskey, G.L., Baheerathan, R., Dougall, C., Ellis, R., Bennett, F.R., Waters, D., Darr, S., Fentie, B., Hateley, L.R., Askildsen, M., 2021. Modelled estimates of fine sediment and particulate nutrients delivered from the Great Barrier Reef catchments. Mar. Pollut. Bull. 165, 112163. https://doi.org/10.1016/j.marpolbul.2021.112163

Meyer, L., Willoughby, W., Whisler, F., Rhoton, F., 1983. Predicting size distributions of sediment eroded from aggregated soils. Trans. Am. Soc. Agric. Eng. 26, 486-490. https://doi.org/10.13031/2013.33962

Meyer, L.D., 1985. Interrill erosion rates and sediment characteristics, in: El-Swafify, S.A., Molendauer, W.C., Lo, A. (Eds.), Soil Erosion and Conservation. Soil Conservation Society of America, Ankent, Iowa.

Meyer, L.D., Harmon, W.C., McDowell, L.L., 1980. Sediment sizes eroded from rowcrop sideslopes. Trans. Am. Soc. Agric. Eng. 23, 891-898.

Miles, R.L.R., Johnston, P.W.P., 1990. Run-off and soil loss from four small catchments in the mulga lands of south west Queensland, in: Proceedings of 6th Australian Rangeland Conference. Carnarvon, W. Aust. Australian Rangeland Society, pp. 170-184.

Renard, K.G., Foster, G.A., Waters, D.K., McCool, D.K., Yoder, D.C., 1997. Predicting soil erosion by water: A guide to conservation planning with the Revised Universal Soil Loss Equation. U.S. Department of Agriculture, Agriculture Handbook N. 703.

Scanlan, J.C., Pressland, A.J., Myles, D.J., 1996. Runoff and soil movement on mid-slopes in North-East Queensland grazed woodlands. Rangel. J. 18, 33-46.

Shaw, M., Silburn, M. (Eds.), 2016. Modelling changes in pollutant loads due to improved management practices in the Great Barrier Reef catchments : Paddock Modelling, Technical Report; Report Cards 2010 to 2013. Department of Natural Resources and Mines, Brisbane, Qld.

Silburn, D.M., 2011. Hillslope runoff and erosion on duplex soils in grazing lands in semi-arid central Queensland. III. USLE erodibility (K factors) and cover-soil loss relationships. Soil Res. 49, 127-134. https://doi.org/10.1071/SR09070

Silburn, D.M., 1994. Mt. Mort field visit - Februray 1994, in: Field Trip Notes - Eastern Darling Downs and Lockyer Valley. Second International 'Symposium on Sealing, Crusting, Hardsetting Soils: Productivity and Conservation’, 7-11 February 1994, The University of Queensland, Brisbane, Australia., p. 8.

Silburn, D.M., Carroll, C., Ciesiolka, C.A.A., DeVoil, R.C., Burger, P., 2011. Hillslope runoff and erosion on duplex soils in grazing lands in semi-arid central Queensland. I. Influences of cover, slope, and soil. Soil Res. 49, 105-117. https://doi.org/10.1071/SR09068

Soil Survey Staff, 1999. Soil taxonomy. Agricultural Handbook No. 436. Soil Conservation Service, Washington.

Thornton, C.M., Elledge, A.E., 2019. Agricultural land management practices and water quality in the Fitzroy Basin. Technical report for the 2015 to 2019 hydrological years. Report to the Queensland Reef Water Quality Program. Department of Natural Resources, Mines and Energy, Australia.

Waters, D., 2014. Modelling reductions of pollutant loads due to improved management practices in the Great Barrier Reef catchments, Whole of GBR, Technical Report Volume 1. Queensland Department of Natural Resources and Mines, Toowoomba, Queensland. Toowoomba, Qld.

Wilkinson, S.N., Dougall, C., Kinsey-Henderson, A.E., Searle, R.D., Ellis, R.J., Bartley, R., 2014. Development of a time-stepping sediment budget model for assessing land use impacts in large river basins. Sci. Total Environ. 468-469, 1210-1224. https://doi.org/10.1016/j.scitotenv.2013.07.049

Young, R.A., 1980. Characteristics of eroded sediment. Trans. Am. Soc. Agric. Eng. 23. https://doi.org/10.13031/2013.34735 